\title{
A novel method for predicting fracture in floating ice
}

\author{
Liz LOGAN, ${ }^{1}$ Ginny CATANIA, ${ }^{1,2}$ Luc LAVIER, $^{1,2}$ Eunseo $\mathrm{CHOI}^{3}$ \\ ${ }^{1}$ Department of Geological Sciences, University of Texas at Austin, Austin, TX, USA \\ E-mail: es1359@gmail.com \\ ${ }^{2}$ Institute for Geophysics, University of Texas at Austin, Austin, TX, USA \\ ${ }^{3}$ Center for Earthquake Research and Information, University of Memphis, Memphis, TN, USA
}

\begin{abstract}
Basal crevasses may play an important precursory role in determining both the location and propagation of rifts and iceberg dimensions. For example, icebergs calved recently from Thwaites Glacier, Antarctica, have the same width as surface undulations, strengthening the connection between basal crevasses, rifting and calving. We explore a novel method for estimating the heights of basal crevasses formed at the grounding lines of ice shelves and ice streams. We employ a thin-elastic beam (TEB) formulation and tensional yielding criterion to capture the physics of flexed ice at grounding lines. Observations of basal crevasse heights compare well with model predictions in the Siple Coast region of the Ross Ice Shelf. We find that the TEB method is most accurate in areas of low strain rate. We also test the method in other areas of Antarctica to produce order-of-magnitude maps of grounding-line basal crevasses and find general agreement with reported observations assuming basal crevasses develop in spatio-temporal sequence and are advected downstream. This method is computationally cheap and could be relatively easy to implement into damage-oriented large-scale ice models which aim at physically simulating calving and fracture processes.
\end{abstract}

\section{INTRODUCTION}

Fast-moving glaciers and ice streams discharge across their grounding lines into ice shelves or floating tongues that provide a retarding force for grounded ice flowing into the ocean. There have been several recent observations of collapse or retreat of these floating regions in Antarctica, including the Wilkins, Wordie and Larsen B ice shelves, as well as Thwaites Glacier (Doake and Vaughan, 1991; Joughin and others, 2008; Braun and others, 2009; Scambos and others, 2009; MacGregor and others, 2012). One spectacular example is the collapse of the Larsen B ice shelf, which resulted in the acceleration of glaciers that fed the ice shelf by as much as five times their original flow speeds, an acceleration that has since largely been sustained over the past decade (Scambos and others, 2003; Rott and others, 2011). Ice-shelf disintegration and calving are intrinsically linked to the formation of ice-shelf fractures, including surface and basal crevasses (Doake and others, 1998; MacAyeal and others, 2003; Scambos and others, 2003, 2009; Glasser and Scambos, 2008). Crevasses form in response to - and thus relieve - locally high tensional stresses, and their presence affects the strength of ice (Glasser and Scambos, 2008; McGrath and others, 2012a). Thus, to accurately predict calving in numerical models it may be necessary to first understand the circumstances and patterns under which both surface and basal crevasses initialize, propagate and are advected (Albrecht and Levermann, 2012; Duddu and Waisman, 2013). Accurate and computationally inexpensive methods for predicting crevasse heights can yield extra insight into the timing and predicted calving style of ice shelves, as the time it takes for a crevasse to penetrate the thickness of the ice directly affects the calving rate (Kenneally and Hughes, 2006). State-of-the-art ice-sheet models either use empirical and heuristic calving laws which do not capture all types of calving behavior and are not physically deterministic (e.g. Alley and others, 2008; Levermann and others, 2012) or else neglect the calving problem entirely (e.g. Rutt and others,
2009). In this context, then, the connection between predictive calving laws and crevassing is apparent: the fracture of ice represents the crux of the calving process.

Few have devoted study solely to basal crevasses. Jezek and Bentley (1983) showed basal crevasses to be nearly ubiquitous in the Ross Ice Shelf (RIS). More recent studies have shown basal crevasses to be present in several locations of the Larsen C ice shelf (Luckman and others, 2012; McGrath and others, 2012a,b), on Pine Island Glacier (Bindschadler and others, 2011; Vaughan and others, 2012), the Filchner-Ronne Ice Shelf (Rist and others, 2002) and the Amery Ice Shelf (McGrath and others, 2012b). Basal crevasses have likely played a significant role in the development of rifts which preceded the disintegration of the Wilkins Ice Shelf (Braun and others, 2009). In that case, merging ice streams of different thickness resulted in a bending moment due to buoyancy contrasts which promoted the formation of fractures and rifts. In addition, basal crevasses can be $>100 \mathrm{~m}$ wide at their bases, making them extremely vulnerable to plumes of warm ocean water which can widen the crevasse walls through melt (Weertman, 1973; Van der Veen, 1998a; Khazendar and Jenkins, 2003; Sergienko and MacAyeal, 2005; Bindschadler and others, 2011; McGrath and others, 2012a,b; Vaughan and others, 2012). Finally, two adjacent basal crevasses can create a concave-down ridge between the two basal crevasse crack tips whereby the induced flexure creates corresponding surface crevasses (Luckman and others, 2012; McGrath and others, 2012a,b; Vaughan and others, 2012). Given their seeming ubiquity in floating ice, it is reasonable to suggest that basal crevasses likely existed in the Larsen B ice shelf, and further - as McGrath and others $(2012 a, b)$ show played some role in the initiation of surface crevasses which subsequently filled with meltwater and led to shelf disintegration. Clearly, then, basal crevasses affect the stability of ice shelves, and deserve focus in light of their ubiquity and ability to damage and localize ice-shelf melting, and thus impact calving and sea-level rise. 
a

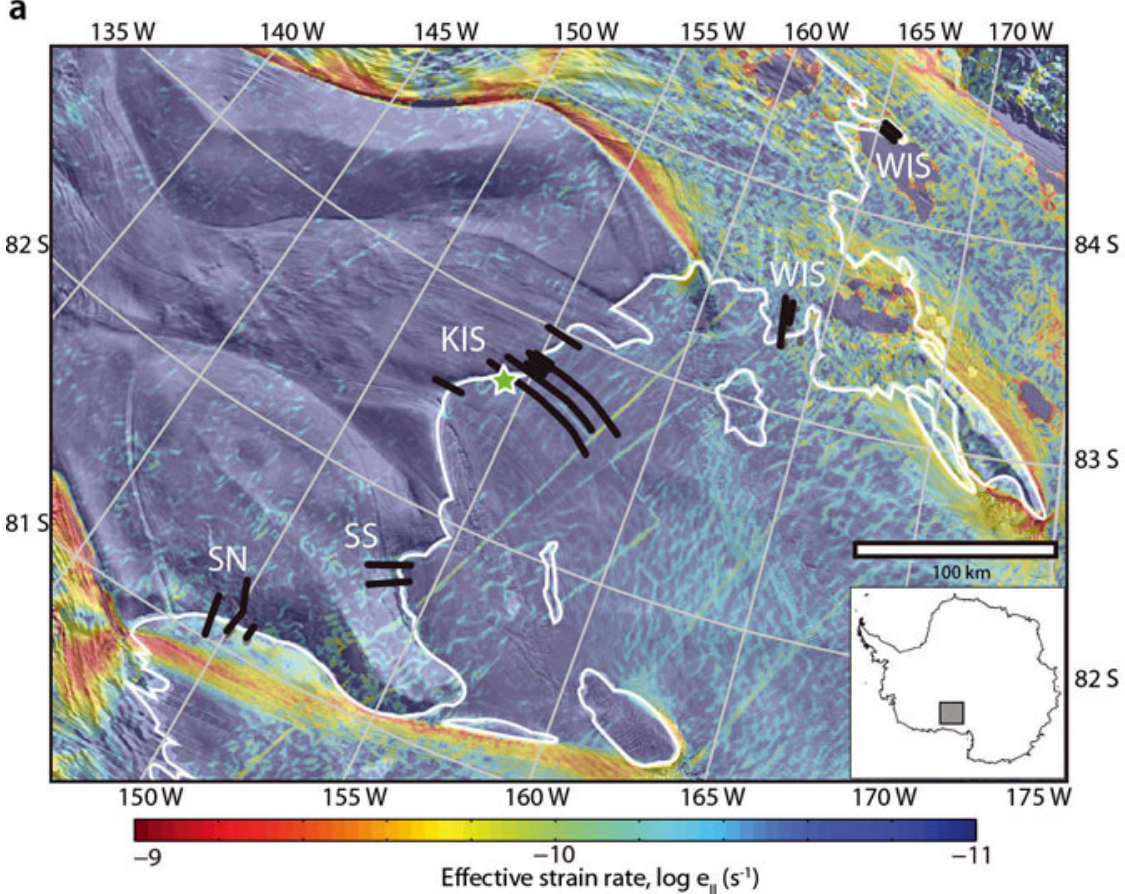

b

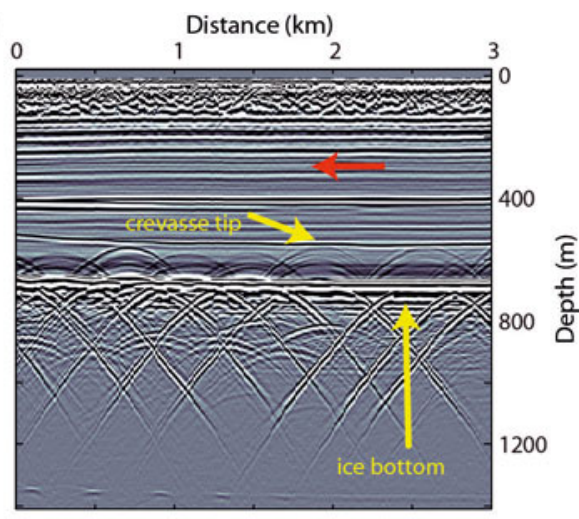

c

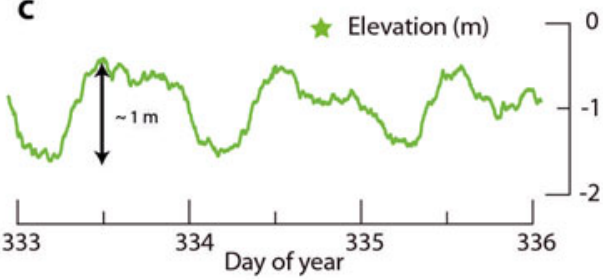

Fig. 1. (a) Locations of radar profiles (thick black lines) at SN, SS, KIS and WIS. Thin white line is the grounding line determined by Horgan and Anandakrishnan (2006). Kinematic GPS was recorded at the grounding line of KIS (green star). Background image is the MODIS Mosaic of Antarctica (MOA; Haran and others, 2005) overlain by a color-scaled logarithmic plot of the computed effective strain rate $\left(\mathrm{s}^{-1}\right)($ Rignot and others, 2011). (b) Example of radar data showing typical hyperbolic diffraction patterns produced by basal crevasse crack tips and the ice/bottom interface (yellow arrows). Direction of ice velocity is shown by the red arrow. (c) Kinematic GPS taken at the location in (a) denoted by the green star. Tidal uplift is $\sim 1 \mathrm{~m}$.

In this paper, we focus on basal crevasses which initiate at grounding lines. The grounding lines of glaciers and ice shelves are dynamic, and their location can change in response to large-scale mass losses or gains. A great effort by many researchers has been undertaken recently to understand the physics and dynamics of this crucial region (e.g. Conway and others, 1999; Shepherd and others, 2001; Rignot and Jacobs, 2002; Schoof, 2007; Jacobs and others, 2012), and state-of-the-art ice-dynamic models continue to develop numerical techniques for appropriately capturing the stresses in this region (e.g. Hindmarsh, 2004; Le Meur and others, 2004; Favier and others, 2012). In this paper, we explore a simple method aimed at reconciling the observations of basal crevasses - fractures often assumed to be expressions of brittle deformation - seen at grounding lines where viscous ice dynamics are important. Our method can provide an upper bound for predicting the heights of basal crevasses formed at grounding lines, motivated by our assumption that these particular features form in response to the bending that occurs as ice begins to float and achieves hydrostatic equilibrium. This method is motivated by a twopart hypothesis: first, that the extensional stresses here can be approximated by a thin elastic beam (TEB) formulation (Timoshenko and Woinowsky-Krieger, 1959; Bodine and Watts, 1979; Turcotte and Schubert, 1982), and second, that yielding occurs by brittle mode I failure (Schulson and Duval, 2009, ch.10). We test our hypotheses against observations of basal crevasses detected from ice-penetrating radar in the Siple Coast region of the RIS, and extend the test to other regions of interest in Antarctica. This method is computationally cheap and could be easy to incorporate into any damage formulation or large-scale ice-dynamic model. Further, areas of TEB-model failure indicate that a more complicated constitutive model may be appropriate. Thus using this method to delineate areas of misfit provides modelers with a metric that can help optimize the use of computationally expensive numerical techniques.

\section{METHODS}

We observed basal fracture diffraction patterns in the Siple Coast region of the RIS using ice-penetrating radar and modeled their propagation heights. Basal crevasses were imaged using a ground-based radar system towed along 19 separate transects (Fig. 1a). The radar data (Fig. 1b) were acquired and processed as described in Catania and others (2010). We identified basal crevasses in the data by picking the apex of the hyperbolic diffraction near the ice/bed interface commonly assumed to result from basal crevasses (e.g. Jezek and Bentley, 1983). We also use Landsat-7 Enhanced Thematic Mapper Plus (ETM+) band 8 imagery (15 m resolution; Cavalieri and Ivanoff, 2009) to observe topographic depressions commonly thought to result from basal crevasses (Bindschadler and others, 2011; McGrath and others, 2012a,b; Vaughan and others, 2012) at the Thwaites Glacier grounding line to examine the connection between basal crevasses and calving in this area.

\section{Loading via flexure}

Much of the previous work done to understand the formation of both surface and basal crevasses has proceeded based on the assumption that crevasses are mode I fractures resulting from high extensional stress (e.g. Weertman, 1973; Van der Veen, 1998a,b; Rist and others, 2002; Mottram and Benn, 2009; Luckman and others, 2012; McGrath and others, 2012a,b). When these formulations have been tested 


$$
\omega^{\prime \prime}(x)=\frac{\omega_{1}-2 \omega_{2}+\omega_{3}}{d x^{2}}
$$

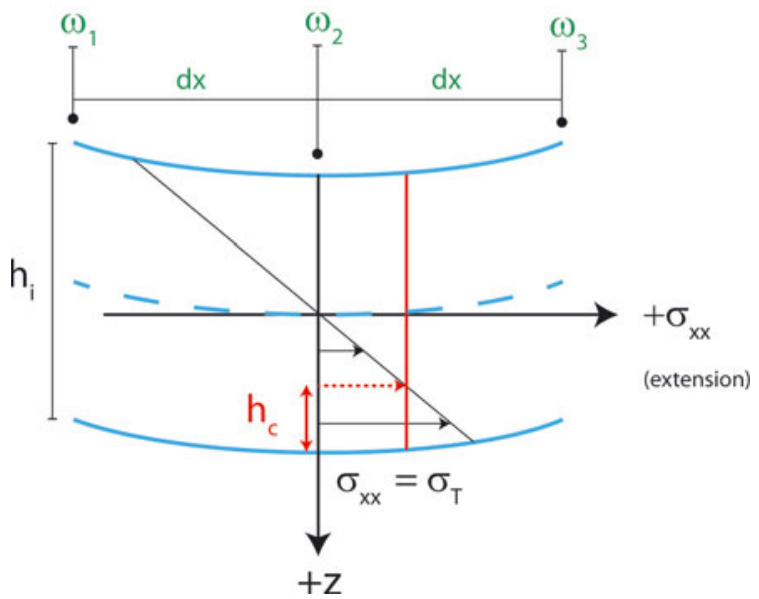

Fig. 2. Schematic diagram of a characteristic thin beam. The applied bending moment compresses the upper half and extends the lower half of the beam. Extensive stress is positive; depth below the neutral plane (dashed blue line) is positive. The tensional yield strength (vertical red line) indicates where the beam can no longer support stress in tension ( $h_{\mathrm{c}}$ the basal crevasse height, red arrow). The stress profile depends on ice thickness $\left(h_{\mathrm{i}}\right)$ and curvature which is the second derivative of topography along the beam axis, in the $x$ direction $\left(\omega^{\prime \prime}{ }_{x}\right.$, green text), as well as Young's modulus and Poisson's ratio.

against in situ crevasse depth measurements, the local background stress (often approximated as the stress which produced the crack) must be estimated, and is typically assumed to be a viscous stress given by the local strain-rate field. In dynamic regions, such as glacier termini (Mottram and Benn, 2009) and highly straining areas of floating ice shelves (Rist and others, 2002; Luckman and others, 2012; McGrath and others, 2012a,b), this assumption is largely justified and has been fairly successful in reproducing observed surface and basal crevasse depths and heights. Along the Siple Coast grounding line (particularly the slowmoving areas of Siple Dome and Kamb Ice Stream) the low strain rates beg another model (Fig. 1a, the second invariant of strain rate calculated from Rignot and others, 2011). Similarly, we assume that basal crevasses in the Siple Coast result from high extensional stresses, but we explore the idea that flexure produces sufficiently high stresses for the ice to fail. This formulation requires that crevasses never extend higher than half the thickness of the ice at the grounding line where they initiate, as they would be propagating into ice which is in compression rather than extension (our data show this to be the case).

Other authors (e.g. Hughes, 1983; Jezek and Bentley, 1983; Langhorne and Haskell, 2004) have posited that grounding-line basal crevasses result from cyclic tidal flexure. Correspondingly, our ice-penetrating radar data show that basal crevasses only appear at and downstream of the grounding line, as the grounding line represents a hinge in the tidal flexing process. Flexural bending that occurs due to tides has been well documented (Vaughan, 1995; Horgan and Anandakrishnan, 2006; Brunt and others, 2010a,b), and kinematic GPS from our campaign shows that in this region the tides flex the grounding line by $\sim 1 \mathrm{~m}$ (Fig. 1c). However, the most striking topographic feature in this area is the slope break, an ice surface feature which results from the ice decoupling from the bed and achieving hydrostatic flotation (Horgan and Anandakrishnan, 2006; Sayag and Worster, 2011; Schoof, 2011). Spatial changes in ice surface slope due to spatial changes in basal boundary conditions (resting on solid material to floating on water) can be seen in both elastic and viscous media (Sayag and Worster, 2011; Schoof, 2011). The Glen-derived (Glen, 1955) viscous creep law used in other studies (Mottram and Benn, 2009; McGrath and others, 2012a,b) to estimate the stress field yields stresses an order of magnitude smaller than stresses calculated via beam flexure and slope break. Curvatures derived from tidal bending versus those due to hydrostatic flotation reveal that slope-break-derived curvatures are 1-2 orders of magnitude larger than those calculated by a $1 \mathrm{~m}$ tidal uplift. Thus we propose that a flexed TEB formulation may capture the loading mechanism responsible for the basal crevasses we imaged.

Having properly motivated our use of the thin-beam stress formulation (ice thickness $\ll$ bending wavelength and the slope-break deflection is sufficiently small), the longitudinal stress induced by a flexed beam has the following form:

$$
\sigma_{x x}=k y \omega^{\prime \prime}(x)
$$

where $y$ is the positive depth in the beam below the neutral plane (Fig. 2), $\omega^{\prime \prime}(x)$ is the topographic curvature in the $x$ direction and

$$
k=E\left(1-\nu^{2}\right)
$$

where $E$ and $\nu$ are the Young's modulus and Poisson's ratio of the material (Timoshenko and Woinowsky-Krieger, 1959; Bodine and Watts, 1979; Turcotte and Schubert, 1982). Reported Young's modulus values vary depending on fieldand laboratory-derived measurements, and we test values between 1 and 10 GPa (Vaughan, 1995; Schulson and Duval, 2009). We assume Poisson's ratio to be $\nu=0.325$ (Gammon and others, 1983; Schulson and Duval, 2009).

Curvature is simply the second derivative of the ice topography field, and we interpolate the surface elevation field normal to the grounding line (Le Brocq and others, 2010) to calculate its second derivative. The resolution of the surface elevation and grounding-line data is $5 \mathrm{~km}$. Curvatures from this dataset showed good agreement with curvatures calculated from kinematic GPS along our radar transects at 1,3 and $5 \mathrm{~km}$ spacings. The average flexural distance of the RIS is $3.2 \mathrm{~km}$, with a standard deviation of $2.6 \mathrm{~km}$, so our use of the $5 \mathrm{~km}$ topographic resolution is reasonable (Brunt and others, 2010b).

The thin beam model assumes that the ice-shelf surface topography is reflective of the curvature at its neutral depth, where flexed ice transitions from extending to compressing. We see no drastic decreases in ice thickness throughout the radar data and proceed under the assumption that the depth to the neutral plane is constant near the grounding line and reflected by the ice surface topography. The curvature field calculated from the topographic data reveals areas of negative curvature (where surface is concave-down and would be extending rather than compressing) but these are on average smaller than the positive curvature values, and further, might instead result from ice surface vertical sinking produced by two adjacent basal crevasses (McGrath and others, 2012a,b; Vaughan and others, 2012). These authors attribute surface cracks between basal crevasses to this type of surface flexure. 
We assume that there is no vertical load on the beam (as our static formulation obviates the inclusion of transient vertical forces, such as tides), and, because the deflection due to buoyancy is small compared to the deflection in Sayag and Worster (2011), the internal shear stresses are correspondingly small. Additionally, the strain rates in this study region are small compared to other studies (e.g. Luckman and others, 2012; McGrath and others, 2012b), so we do not include an in-plane stress in the formulation, which could accommodate for the extra viscous stresses seen elsewhere. In other regions where there is a large inplane stress (i.e. areas of high strain rate) the compression in the upper half of the beam can be overcome, shifting the neutral plane higher, resulting in basal crevasses that penetrate to heights greater than half the thickness of the ice (as in McGrath and others, 2012a). If the in-plane stress is high enough, the crack tip can propagate the full thickness of the ice, allowing the basal crevasse to develop into a rift.

\section{Yielding criterion}

There are two common formulations used to predict fracture propagation length in ice (for both surface and basal crevasses): the 'zero-stress' model (Nye, 1955) and linear elastic fracture mechanics (LEFM) (Van der Veen, 1998a,b; Mottram and Benn, 2009). Both methods require knowledge of the local stress field. If the stress is assumed to result from viscous deformation, both models must assume two material flow-rate parameters which derive from viscous creep flow laws (Goldsby and Kohlstedt, 2001; Mottram and Benn, 2009). The 'zero-stress' model has been further modified to allow for tuning of a yield strain rate where crevasse depth or height data have been available (Vaughan, 1993; Mottram and Benn, 2009). Similarly, LEFM represents material yielding in the form of the critical stress intensity factor (Van der Veen, 1998a,b). Where crevasses have been observed in equilibrium with the surrounding stress field, both yielding criteria have been applied with success. In other cases, where crevasses are not obviously in equilibrium with the surrounding stress state (Mottram and Benn, 2009) or evidence exists indicating mixed-mode fracture (series 2 crevasses in Luckman and others, 2012), the 'zerostress' model and LEFM tend to overestimate or underestimate crevasse depths respectively, sometimes by a factor of 2-3. Regarding the speed at which the fracture tip propagates, if cracks are assumed to form quickly, such that the mechanical energy needed to form new crevasse wall surfaces is not dissipated through viscous creep deformation, LEFM is a valid yield formulation. Assuming instead that crevasses form slowly, the 'zero-stress' model or subcritical crack formulation (Weiss, 2004) may be more applicable (Schulson and Duval, 2009).

Based on our loading assumption and its computational simplicity, we instead propose that failure at the grounding line (regardless of the rate of failure) may be estimated as the depth to which the material can no longer support stress in tension. That is, brittle deformation occurs when stress exceeds a given yield strength. Thus when $\sigma_{x x}$ is equal to a certain tension limit $\sigma_{T}$, we can solve for the thickness of the beam that exceeds the tensional yield strength. This would be the height to which a grounding-line basal crevasse can propagate, given by

$$
h_{\mathrm{c}}=\frac{h_{\mathrm{i}}}{2}-\frac{\sigma_{T}}{\left(k \omega^{\prime \prime}\right)}
$$

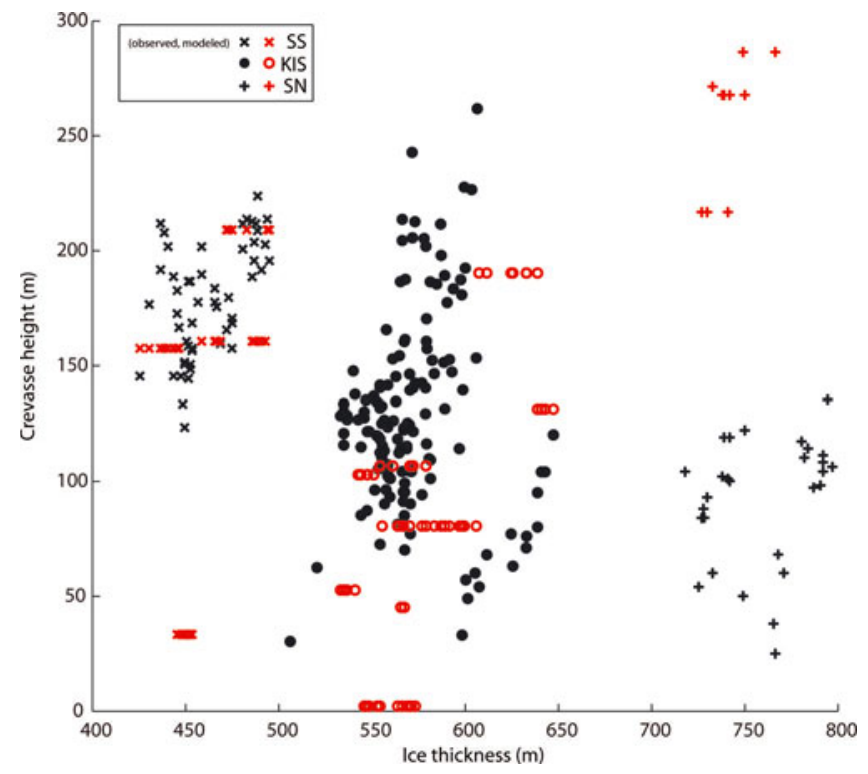

Fig. 3. Predicted (red) vs observed (black) basal crevasse heights. Most predictions are within the range of observation. Two areas of misfit can be attributed to high in-plane viscous stress ( $\mathrm{SN}$ is collocated with Bindschadler Ice Stream shear margin) and previous grounding-line location (SS). No crevasses are predicted for WIS, owing to its very low curvature as an ice plain.

where $h_{\mathrm{i}}$ is the ice thickness and $k$ is as in Eqn (2). A large literature of laboratory-derived yield strengths exists (Schulson and Duval, 2009, ch. 10 references). The yield strength for laboratory-prepared ice samples depends on many factors, including crystal size, preparation method, loading method and ice temperature, but is generally $1 \mathrm{MPa}$. From $-30^{\circ} \mathrm{C}$ to $0^{\circ} \mathrm{C}$ the tensional strength of ice is $1.1-1.0 \mathrm{MPa}$ (Schulson and Duval, 2009).

\section{RESULTS AND DISCUSSION}

We applied TEB theory to grounding lines throughout Antarctica and, where possible, compared the model results to observations of basal crevasses.

\section{Siple Coast}

We observed 256 basal crevasse diffraction patterns in 19 separate radar transects covering four different regions in the Siple Coast: Siple Dome North (SN), Siple Dome South (SS), Kamb Ice Stream (KIS) and Whillans Ice Stream (WIS). We found an inverse relationship between crevasse height and ice thickness (Fig. 3, black points), which can be explained using a TEB framework if the maximum bending stress for thicker ice is less than the maximum bending stress for thinner ice (Fig. 4). This implies that the buoyancy-induced curvature for thicker ice is less than that for thinner ice.

Table 1 shows the mean and standard deviation of the difference between the observed and modeled values for different values of Young's modulus. No crevasses were predicted for the field-derived Young's modulus estimate of 1 GPa (Vaughan, 1995). The reason this value produces no estimates is not obvious, but we suggest that it may better represent grounding lines characterized by higher strain rates or may reflect lack of certainty in ice thickness when the estimates were made, as the method used to estimate the Young's modulus is highly sensitive to ice thickness. 
a

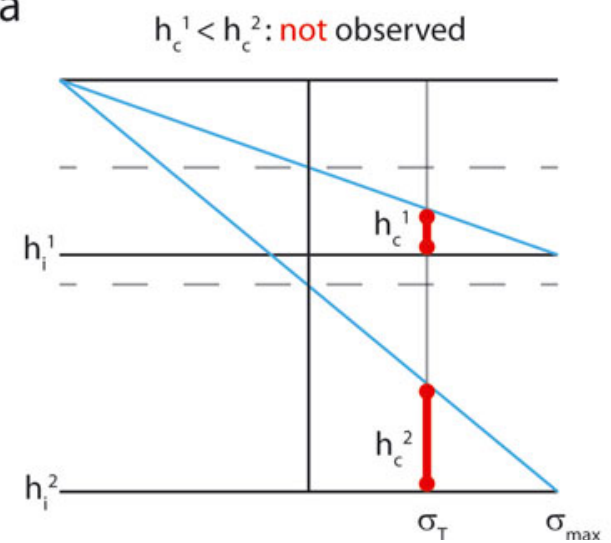

b

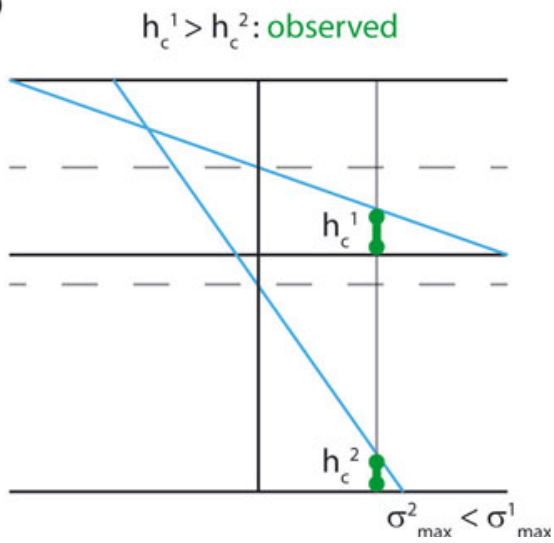

Fig. 4. (a) Basal crevasses resulting from the same flexure applied to thinner $\left(h_{\mathrm{i}}{ }^{1}\right)$ and thicker ice $\left(h_{\mathrm{i}}{ }^{2}\right)$. Thicker ice produces larger crevasses than thinner ice; this is not what we observe. (b) For smaller basal crevasses in thicker ice, it must be true that thicker ice experiences less induced bending stress $\left(\sigma^{2}{ }_{\max }\right)$ than thinner ice $\left(\sigma_{\max }^{1}>\sigma_{\max }^{2}\right)$.

Figure 3 shows the TEB model produces results within the range in observation, with two noteworthy exceptions. Basal crevasse heights at $\mathrm{SN}$ are predicted to be three times higher than observed. Close examination of strain rates in this region (Fig. 1a) reveals that our observed basal crevasses are in close proximity to the Bindschadler Ice Stream southern shear margin. Indeed, the ice velocity seaward of the grounding line is transverse to our radar lines in this area. We conclude that the observed misfit at $\mathrm{SN}$ is indicative of high shear stresses (i.e. viscous in-plane stress), and a more complex or mixed-mode fracture model needs to be considered where the grounding line is co-located with ice-stream shear margins. Another location of misfit results at SS, for which our underestimated crevasses lie in a region complicated by changes in ice flow (Catania and others, 2006; Fig. 1a). Indeed, Catania and others (2010) imaged a former grounding line upstream of its present location and it is possible that these basal crevasses formed long ago, when the direction and magnitude of grounding line flexure may have been different. Additionally, the geometry of the grounding line at this location is curved, and could indicate that the direction of flexure is more complicated than a onedimensional stress formulation allows. TEB theory predicts no basal crevasses for WIS, for which only a few, comparatively short $(<50 \mathrm{~m}$ in height) basal crevasses were

Table 1. Mean $(N)$ and standard deviation $(\sigma)$ of the absolute value of difference between observed and predicted crevasse heights for all four regions, tested against several values of Young's modulus. No crevasses were predicted using $E=1 \mathrm{GPa}$ (Vaughan, 1995). The value which minimizes the difference for all locations was $10 \mathrm{GPa}$; $5 \mathrm{GPa}$ minimizes the difference for KIS and SN while 7.5 GPa minimizes the difference for SS. ${ }^{*}$ denotes minimum for a particular group

\begin{tabular}{lrrrrrr}
\hline & \multicolumn{2}{c}{$5 \mathrm{GPa}$} & \multicolumn{2}{c}{$7.5 \mathrm{GPa}$} & \multicolumn{2}{c}{$10 \mathrm{GPa}$} \\
& $N$ & $\sigma$ & $N$ & $\sigma$ & $N$ & $\sigma$ \\
& & & & & & \\
\hline AII & 80 & 53 & 86 & 49 & $* 77$ & 53 \\
SS & 101 & 46 & $* 51$ & 25 & 62 & 47 \\
KIS & $* 13$ & 10 & 102 & 44 & 73 & 43 \\
SN & $* 66$ & 46 & 130 & 52 & 169 & 47
\end{tabular}

observed. WIS has a well-noted ice plain and undergoes a more diffuse ungrounding than more classic grounding lines (Bindschadler, 1993; Winberry and others, 2009; Walter and others, 2011), so it is not surprising that the topography of WIS is not sufficiently curved to produce large $(>100 \mathrm{~m})$ crevasse heights, as in the other areas.

\section{Other areas}

We perform the same analysis (Fig. 5) on other grounding lines around Antarctica. The TEB model is most sensitive to curvature and predicts basal crevasses to exist at nearly all grounding lines. Our observations of 256 basal crevasses in the Siple Coast spanning four dynamically different grounding zones suggest that it may be reasonable for basal crevasses to exist without the associated topographic undulations typically used to infer their presence. It is also reasonable, however, that the assumptions which may be justified in the Siple Coast are not necessarily true elsewhere. Namely, our assumption that in-plane viscous stress is negligible is certainly not justified for all grounding lines around Antarctica, and this must be remembered when applying the TEB method elsewhere. Further, it is unlikely that any basal crevasses initiated through bending at the grounding line remain unmodified as they enter changing environments, either by melting/refreezing or by additional strain as the basal crevasses enter faster-moving areas of the ice shelf. Basal crevasse heights could easily be modified by the time they reach the locations where other authors have observed them, so we approach the analysis simply to explore the order-of-magnitude accuracy of the TEB method under the assumption that basal crevasses form in temporal sequence and are advected downstream to regions where others have observed them.

Several isolated examples of basal crevasses forming midshelf in the Larsen $\mathrm{C}$ ice shelf have been explored where bending cannot be invoked as an explanation (Luckman and others, 2012; Figs $2 \mathrm{~b}$ and 5a, c and d). Here the propagation heights of basal crevasses were modeled using a viscous stress model and LEFM as a yielding criterion, with moderate success. Closer to grounding lines, Luckman and others (2012) and McGrath and others (2012a,b) also observed long trains of basal crevasses $\sim 100 \mathrm{~m}$ in height emerging near the shear margins of the Joerg and Churchill Peninsulas (Fig. 5a). The TEB method estimates grounding-line basal 

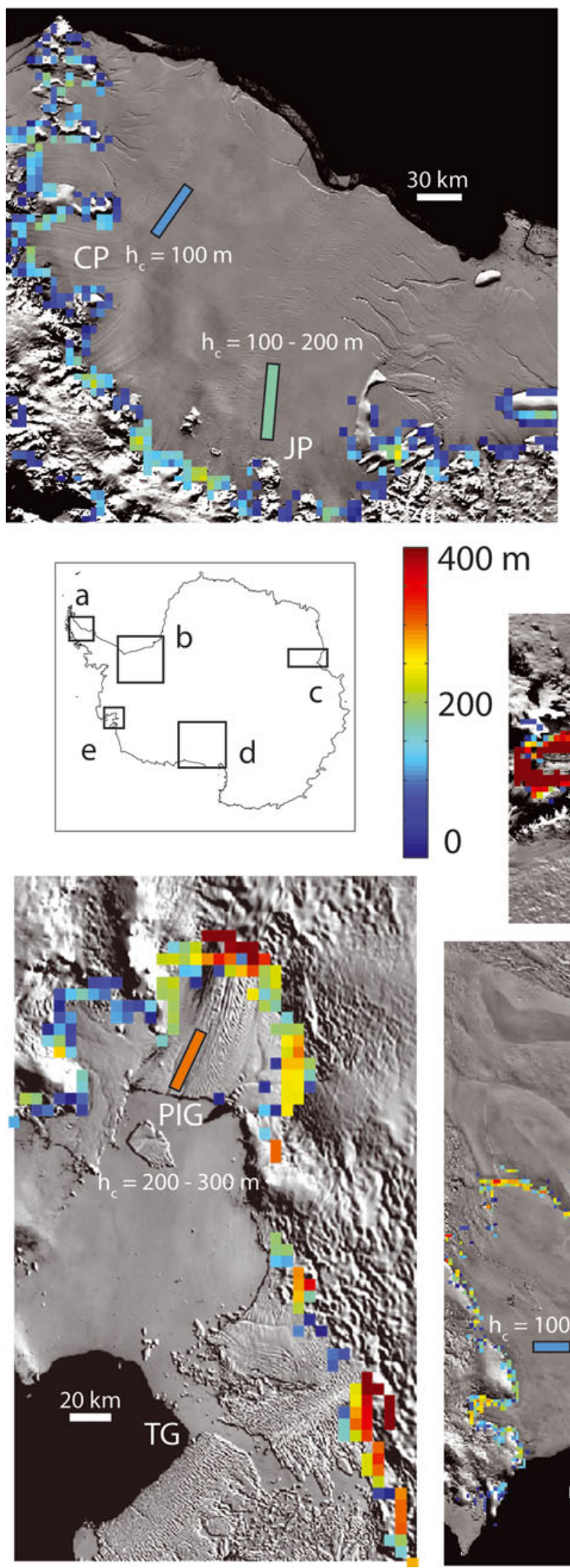

$400 \mathrm{~m}$
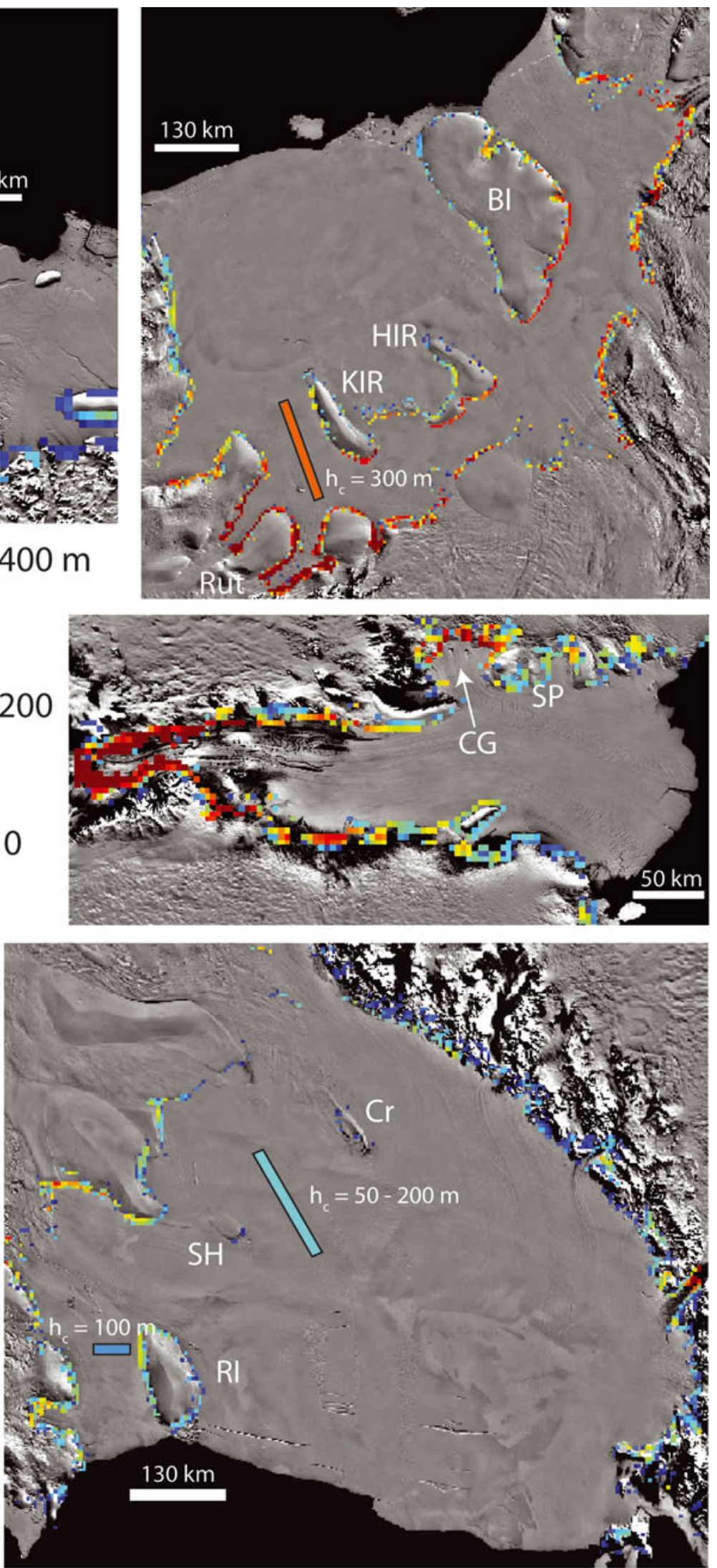

Fig. 5. MOA images overlain by the TEB-predicted basal crevasse heights, indicated by color bar. Colored boxes with black outline are the approximate location and observed basal crevasse height from other radar studies. (a) Larsen $\mathrm{C}$ ice shelf compared with observations at Churchill (CP) and Joerg Peninsulas (JP) (Luckman and others, 2012; McGrath and others, 2012a); (b) Filchner-Ronne Ice Shelf showing basal crevasses stemming from Rutford Ice Stream (Rut), Kirchoff (KIR) and Henry (HIR) Ice Rises and Berkner Island (BI) (Rist and others, 2002); (c) Amery Ice Shelf; undulated topography directly downstream of Charybdis Glacier (CG) and Single Promontory (SP); (d) Ross Ice Shelf (Jezek and Bentley, 1983); Roosevelt Island (RI; Catania and others, 2010); rifts develop directly downstream of Steershead (SH) and Crary (Cr) Ice Rises shown by basal crevasses; (e) Pine Island (PIG; Bindschadler and others, 2011) and Thwaites Glaciers (TG); central rift in Thwaites Glacier develops directly downstream of high basal crevasses and shear margin. Large topographic undulations appear directly downstream of where high basal crevasses would be predicted in Pine Island Glacier. 


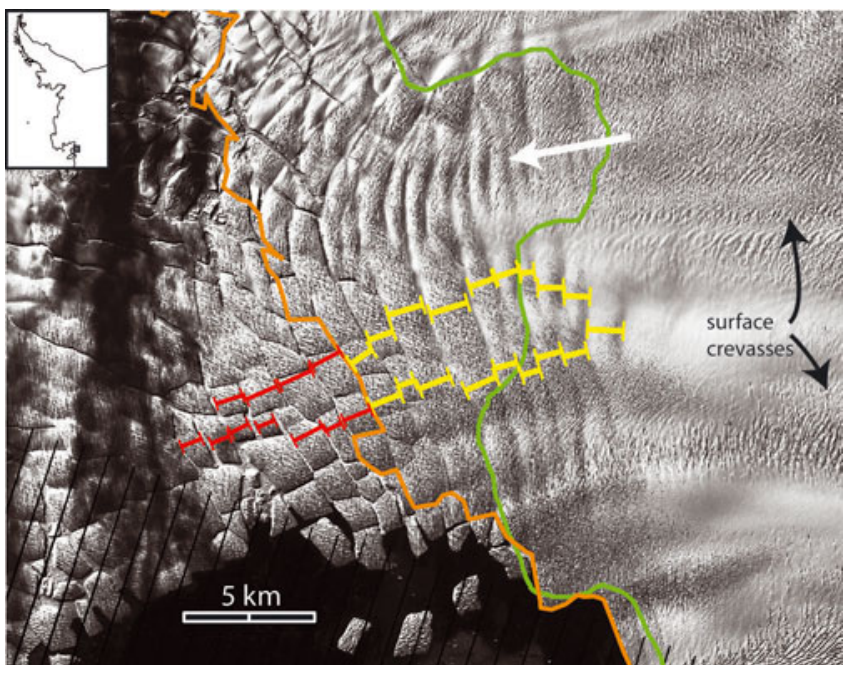

Fig. 6. Landsat-7 ETM+ band 8 ( $15 \mathrm{~m}$ resolution) image of Thwaites Glacier (from January 2013) and MOA-derived grounding line (green line). Ice velocity is indicated by the thick white arrow. Surface crevasses appear as highly textured areas indicated by the black arrows. Spacing between topographic undulations (yellow bars) is compared to iceberg width (red bars). Ice still connected to TG is upstream of the calving front (orange line). Average distance between surface depressions is $1034 \mathrm{~m}$; average width of icebergs is $1035 \mathrm{~m}$ (standard devations 217 and $224 \mathrm{~m}$, respectively).

crevasse heights of $\sim 100-150 \mathrm{~m}$ at the grounding line upstream of, and shear margin directly adjacent to, these observations. Ice is shearing along these margins, so this may represent an overestimate, just as at $\mathrm{SN}$, where the grounding-line curvature and strain rates were similarly high. In the Filchner-Ronne Ice Shelf, Rist and others (2002) observed basal crevasses far from the grounding line of Rutford Ice Stream (Fig. 5b) of order $300 \mathrm{~m}$ in height. The TEB method estimates grounding-line basal crevasses forming upstream of these observations $\sim 400 \mathrm{~m}$ in height, and it may be that a combination of viscous deformation and basal melting can account for the misfit.

The TEB method also predicts basal crevasses to be present at the grounding lines of large pinning islands and ice rises such as Berkner Island and Korff and Henry Ice Rises (Filchner-Ronne Ice Shelf, Fig. 5b) as well as Roosevelt Island and Crary and Steershead Ice Rises (RIS, Fig. 5d). Catania and others (2010; Fig. 5a) imaged the eastern margin of Roosevelt Island and observed basal crevasses there between 100 and $130 \mathrm{~m}$ in height. The TEB prediction overestimates this value by $\sim 50 \mathrm{~m}$ (Fig. $5 \mathrm{~d}$ ). We again attribute this overestimation to high shear stresses, as in the case of $\mathrm{SN}$, where these observations were made along a shear margin.

Most striking from the TEB crevasse maps is that regions of topographically undulated flowbands often follow directly downstream of areas in which the approximation predicts relatively high basal crevasse heights, strengthening the idea that basal crevasses can play a central role in determining the location of rifts and large-scale ice-shelf damage. One such location appears on the Amery Ice Shelf (Fig. 5c) stemming from Charybdis Glacier: surface depressions appear close to the grounding line and, after rounding Single Promontory, develop into a long train of undulated topography that approaches the calving front. Additionally, the topographically undulated zones on the floating shelves of Pine Island (PIG) and Thwaites Glaciers (TG) appear directly downstream of locations where TEB-predicted basal crevasses appear to be comparatively large (Fig. 5e).

While both PIG and TG are fast-flowing and have experienced recent dynamic changes, including high basal melt rates and grounding-line retreat (e.g. Bindschadler and others, 2011; Vaughan and others, 2012), a close inspection of the TG grounding line provides further motivation for the inclusion of basal crevasses in ice-dynamic models. A Landsat-7 image from January 2013 (Fig. 6) shows undulated topography which we believe may indicate the onset of basal crevasses. Measurements of the surface depression spacing (yellow bars) were compared to measurements of the freshly calved icebergs (red bars). The average spacing of the surface depressions is $1034 \mathrm{~m}$, and the average width of the freshly calved icebergs is $1035 \mathrm{~m}$ (standard deviations 217 and $224 \mathrm{~m}$, respectively). This suggests that, at least in areas where basal crevasses persist long enough to reach the calving front, iceberg geometry can be controlled to a first order by the spacing of basal crevasses.

\section{CONCLUSIONS}

Our results show that the TEB formulation applied at or upstream of observed basal crevasses produces order-ofmagnitude crevasse heights. The model is more accurate at grounding lines where strain rates are low and may best be used to infer where stresses are dominantly viscous if the misfit between observed and modeled basal crevasse height is large. Additionally, areas where the TEB method predicts comparatively high basal crevasses appear directly upstream of areas of topographically undulated and damaged ice. In light of their ability to determine iceberg geometry in some locations, notably Thwaites Glacier, we suggest it is important to incorporate the effects of basal crevasses when modeling calving processes.

\section{ACKNOWLEDGEMENTS}

This work was supported by US National Science Foundation grant ARC-0941678. We thank Joe MacGregor for assistance with satellite imagery. We also thank two anonymous reviewers and the scientific editor, Neil Glasser, who provided essential feedback and constructive criticism.

\section{REFERENCES}

Albrecht T and Levermann A (2012) Fracture field for large-scale ice dynamics. J. Glaciol., 58(207), 165-176 (doi: 10.3189/ 2012JoG11J191)

Alley RB and 7 others (2008) A simple law for ice-shelf calving. Science, 322(5906), 1344 (doi: 10.1126/science.1162543)

Bindschadler R (1983) The importance of pressurized subglacial water in separation and sliding at the glacier bed. J. Glaciol., 29(101), 3-19

Bindschadler R, Vaughan DG and Vornberger P (2011) Variability of basal melt beneath the Pine Island Glacier ice shelf, West Antarctica. J. Glaciol., 57(204), 581-595 (doi: 10.3189/ 002214311797409802)

Bodine $\mathrm{JH}$ and Watts AB (1979) On lithospheric flexure seaward of the Bonin and Marina Trenches. Earth Planet. Sci. Lett., 43(1), 132-148

Braun M, Humbert A and Moll A (2009) Changes of Wilkins Ice Shelf over the past 15 years and inferences on its stability. Cryosphere, 3(1), 41-56 (doi: 10.5194/tc-3-41-2009) 
Brunt KM, King MA, Fricker HA and MacAyeal DR (2010a) Flow of the Ross Ice Shelf, Antarctica, is modulated by the ocean tide. J. Glaciol., 56(195), 157-161 (doi: 10.3189/ 002214310791190875)

Brunt KM, Fricker HA, Padman L, Scambos TA and $\mathrm{O}^{\prime}$ Neel S (2010b) Mapping the grounding zone of Ross Ice Shelf, Antarctica, using ICESat laser altimetry. Ann. Glaciol., 51(55), 71-79 (doi: 10.3189/172756410791392790)

Catania GA, Conway H, Raymond CF and Scambos TA (2006) Evidence for floatation or near floatation in the mouth of Kamb Ice Stream, West Antarctica, prior to stagnation. J. Geophys. Res., 111(F1), F01005 (doi: 10.1029/2005JF000355)

Catania GA, Hulbe CL and Conway HB (2010) Grounding-line basal melt rates determined using radar-derived internal stratigraphy. J. Glaciol., 56(197), 545-554 (doi: 10.3189/ 002214310792447842)

Cavaliero DJ and Ivanoff A (2009) AMSRice03 Landsat-7 ETM+ Imagery. National Snow and Ice Data Center, Boulder, CO. Digital media: http://nsidc.org/api/metadata?id=nsidc-0431

Conway H, Hall BL, Denton GH, Gades AM and Waddington ED (1999) Past and future grounding-line retreat of the West Antarctic ice sheet. Science, 286(5438), 280-283 (doi: 10.1126/science.286.5438.280)

Doake CSM and Vaughan DG (1991) Rapid disintegration of the Wordie Ice Shelf in response to atmospheric warming. Nature, 350(6316), 328-330 (doi: 10.1038/350328a0)

Doake CSM, Corr HFJ, Rott H, Skvarca P and Young NW (1998) Breakup and conditions for stability of the northern Larsen Ice Shelf, Antarctica. Nature, 391(6669), 778-780 (doi: 10.1038/ 35832)

Duddu R and Waisman H (2013) A nonlocal continuum damage mechanics approach to simulation of creep fracture in ice sheets. Comput. Mech., 51(6), 961-974 (doi: 10.1007/s00466012-0778-7)

Favier L, Gagliardini O, Durand G and Zwinger T (2012) A threedimensional full Stokes model of the grounding line dynamics: effect of a pinning point beneath the ice shelf. Cryosphere, $\mathbf{6}(1)$, 101-112 (doi: 10.5194/tc-6-101-2012)

Gammon PH, Kiefte H, Clouter MJ and Denner WW (1983) Elastic constants of artificial and natural ice samples by Brillouin spectroscopy. J. Glaciol., 29(103), 433-460

Glasser NF and Scambos TA (2008) A structural glaciological analysis of the 2002 Larsen B ice-shelf collapse. J. Glaciol., 54(184), 3-16 (doi: 10.3189/002214308784409017)

Glen JW (1955) The creep of polycrystalline ice. Proc. R. Soc. London, Ser. A, 228(1175), 519-538

Goldsby DL and Kohlstedt DL (2001) Superplastic deformation of ice: experimental observations. J. Geophys. Res., 106(B6), 11 017-11030 (doi: 10.1029/2000JB900336)

Haran T, Bohlander J, Scambos T, Fahnestock $M$ and compilers (2005) MODIS mosaic of Antarctica (MOA) image map. National Snow and Ice Center, Boulder, CO. Digital media: http://nsidc.org/data/nsidc-0280.html

Hindmarsh RCA (2004) A numerical comparison of approximations to the Stokes equations used in ice sheet and glacier modeling. J. Geophys. Res., 109(F1), F01012 (doi: 10.1029/2003JF000065)

Horgan HJ and Anandakrishnan S (2006) Static grounding lines and dynamic ice streams: evidence from the Siple Coast, West Antarctica. Geophys. Res. Lett., 33(18), L18502 (doi: 10.1029/ 2006GL027091)

Hughes T (1983) On the disintegration of ice shelves: the role of fracture. J. Glaciol., 29(101), 98-117

Jacobs S and 6 others (2012) The Amundsen Sea and the Antarctic Ice Sheet. Oceanography, 25(3), 154-163 (doi: 10.5670/ oceanog.2012.90)

Jezek KC and Bentley CR (1983) Field studies of bottom crevasses in the Ross Ice Shelf, Antarctica. J. Glaciol., 29(101), 118-126

Joughin I and 7 others (2008) Continued evolution of Jakobshavn Isbrae following its rapid speedup. J. Geophys. Res., 113(F4), F04006 (doi: 10.1029/2008JF001023)
Kenneally JP and Hughes T (2006) Calving giant icebergs: old principles, new applications. Antarct. Sci., 18(3), 409-419 (doi: 10.1017/S0954102006000459)

Khazendar A and Jenkins A (2003) A model of marine ice formation within Antarctic ice shelf rifts. J. Geophys. Res., 108(C7), 3235 (doi: 10.1029/2002JC001673)

Langhorne PJ and Haskell TG (2004) The flexural strength of partially refrozen cracks in sea ice. In Chung JS, Izumiyama K, Sayed M and Hong SW eds. Proceedings of the 14th International Offshore and Polar Engineering Conference, 23-28 May, 2004, Toulon, France. International Society of Offshore and Polar Engineers, Cupertino, CA, 819-824

Le Brocq AM, Payne AJ and Vieli A (2010) An improved Antarctic dataset for high resolution numerical ice sheet models (ALBMAP v1). Earth Syst. Sci. Data, 2(2), 247-260 (doi: 10.5194/essdd-3-195-2010)

Le Meur E, Gagliardini O, Zwinger T and Ruokolainen J (2004) Glacier flow modelling: a comparison of the Shallow Ice Approximation and the full-Stokes equation. C. R. Phys., 5(7), 709-722

Levermann A, Albrecht T, Winkelmann R, Martin MA, Haseloff M and Joughin I (2012) Kinematic first order calving law implies potential for abrupt ice-shelf retreat. Cryosphere, 6, 273-286 (doi: 10.5194/tc-6-273-2012)

Luckman A, Jansen D, Kulessa B, King EC, Sammonds P and Benn DI (2012) Basal crevasses in Larsen C Ice Shelf and implications for their global abundance. Cryosphere, 6(1), 113-123 (doi: 10.5194/tc-6-113-2012)

MacAyeal DR, Scambos TA, Hulbe CL and Fahnestock MA (2003) Catastrophic ice-shelf break-up by an ice-shelf-fragmentcapsize mechanism. J. Glaciol., 49(164), 22-36 (doi: 10.3189/ 172756503781830863)

MacGregor JA, Catania GA, Markowski MS and Andrews AG (2012) Widespread rifting and retreat of ice-shelf margins in the eastern Amundsen Sea Embayment between 1972 and 2011. J. Glaciol., 58(209), 458-466 (doi: 10.3189/2012JoG11J262)

McGrath D, Steffen K, Scambos T, Rajaram H, Casassa G and Rodriguez Lagos JL (2012a) Basal crevasses and associated surface crevassing on the Larsen C ice shelf, Antarctica, and their role in ice-shelf instability. Ann. Glaciol., 53(60 Pt 1), 10-18 (doi: 10.3189/2012AoG60A005)

McGrath D, Steffen K, Rajaram H, Scambos T, Abdalati W and Rignot E (2012b) Basal crevasses on the Larsen C Ice Shelf, Antarctica: implications for meltwater ponding and hydrofracture. Geophys. Res. Lett., 39(16), L16504 (doi: 10.1029/2012GL052413)

Mottram RH and Benn DI (2009) Testing crevasse-depth models: a field study at Breiðamerkurjökull, Iceland. J. Glaciol., 55(192), 746-752 (doi: 10.3189/002214309789470905)

Nye JF (1955) Correspondence. Comments on Dr. Loewe's letter and notes on crevasses. J. Glaciol., 2(17), 512-514

Rignot E and Jacobs SS (2002) Rapid bottom melting widespread near Antarctic ice sheet grounding lines. Science, 296(5575), 2020-2023 (doi: 10.1126/science.1070942)

Rignot E, Mouginot J and Scheuchl B (2011) Ice flow of the Antarctic Ice Sheet. Science, 333(6048), 1427-1430 (doi: 10.1126/science.1208336)

Rist MA, Sammonds PR, Oerter H and Doake CSM (2002) Fracture of Antarctic shelf ice. J. Geophys. Res., 107(B1), 2002 (doi: 10.1029/2000JB000058)

Rott H, Müller F, Nagler T and Floricioiu D (2011) The imbalance of glaciers after disintegration of Larsen-B ice shelf, Antarctic Peninsula. Cryosphere, 5(1), 125-134 (doi: 10.5194/tc5-125-2011)

Rutt IC, Hagdorn M, Hulton NRJ and Payne AJ (2009) The Glimmer community ice sheet model. J. Geophys. Res., 114(F2), F02004 (doi: 10.1029/2008JF001015)

Sayag R and Worster MG (2011) Elastic response of a grounded ice sheet coupled to a floating ice shelf. Phys. Rev. E, 84(3), 036111 (doi: 10.1103/PhysRevE.84.036111)

Scambos T, Hulbe C and Fahnestock M (2003) Climate-induced ice shelf disintegration in the Antarctic Peninsula. In Domack EW, 
Burnett A, Leventer A, Conley P, Kirby M and Bindschadler R eds. Antarctic Peninsula climate variability: a historical and paleoenvironmental perspective. (Antarctic Research Series 79) American Geophysical Union, Washington, DC, 79-92

Scambos T and 7 others (2009) Ice shelf disintegration by plate bending and hydro-fracture: satellite observations and model results of the 2008 Wilkins ice shelf break-ups. Earth Planet. Sci. Lett., 280(1-4), 51-60 (doi: 10.1016/j.epsl.2008.12.027)

Schoof C (2007) Ice sheet grounding line dynamics: steady states, stability, and hysteresis. J. Geophys. Res., 112(F3), F03S28 (doi: 10.1029/2006JF000664)

Schoof C (2011) Marine ice sheet dynamics. Part 2. A Stokes flow contact problem. J. Fluid Mech., 679, 122-155 (doi: 10.1017/ jfm.2011.129)

Schulson EM and Duval P (2009) Creep and fracture of ice. Cambridge University Press, Cambridge

Sergienko O and MacAyeal DR (2005) Surface melting on Larsen Ice Shelf, Antarctica. Ann. Glaciol., 40, 215-218 (doi: 10.3189/ 172756405781813474)

Shepherd A, Wingham DJ, Mansley JAD and Corr HFJ (2001) Inland thinning of Pine Island Glacier, West Antarctica. Science, 291(5505), 862-864 (doi: 10.1126/science.291.5505.862)

Timoshenko SP and Woinowsky-Krieger S (1959) Theory of plates and shells, 2nd edn. McGraw-Hill, New York

Turcotte DL and Schubert G (1982) Geodynamics: applications of continuum physics to geological problems. Wiley, New York
Van der Veen CJ (1998a) Fracture mechanics approach to penetration of surface crevasses on glaciers. Cold Reg. Sci. Technol., 27(1), $31-47$

Van der Veen CJ (1998b) Fracture mechanics approach to penetration of bottom crevasses on glaciers. Cold Reg. Sci. Technol., 27(3), 213-223 (doi: 10.1016/S0165-232X(98)00006-8)

Vaughan DG (1993) Relating the occurrence of crevasses to surface strain rates. J. Glaciol., 39(132), 255-266

Vaughan DG (1995) Tidal flexure at ice shelf margins. J. Geophys. Res., 100(B4), 6213-6224 (doi: 10.1029/94JB02467)

Vaughan DG and 8 others (2012) Subglacial melt channels and fracture in the floating part of Pine Island Glacier, Antarctica. J. Geophys. Res., 117(F3), F03012 (doi: 10.1029/2012JF002360)

Walter JI, Brodsky EE, Tulaczyk S, Schwartz SY and Pettersson R (2011) Transient slip events from near-field seismic and geodetic data on a glacier fault, Whillans Ice Plain, West Antarctica. J. Geophys. Res., 116(F1), F01021 (doi: 10.1029/2010JF001754)

Weertman J (1973) Can a water-filled crevasse reach the bottom surface of a glacier? IASH Publ. 95 (Symposium at Cambridge 1969 - Hydrology of Glaciers), 139-145

Weiss J (2004) Subcritical crack propagation as a mechanism of crevasse formation and iceberg calving. J. Glaciol., 50(168), 109115 (doi: 10.3189/172756504781830240)

Winberry JP, Anandakrishnan S, Alley RB, Bindschadler RA and King MA (2009) Basal mechanics of ice streams: insights from the stickslip motion of Whillans Ice Stream, West Antarctica. J. Geophys. Res., 114(F1), F01016 (doi: 10.1029/2008JF001035) 